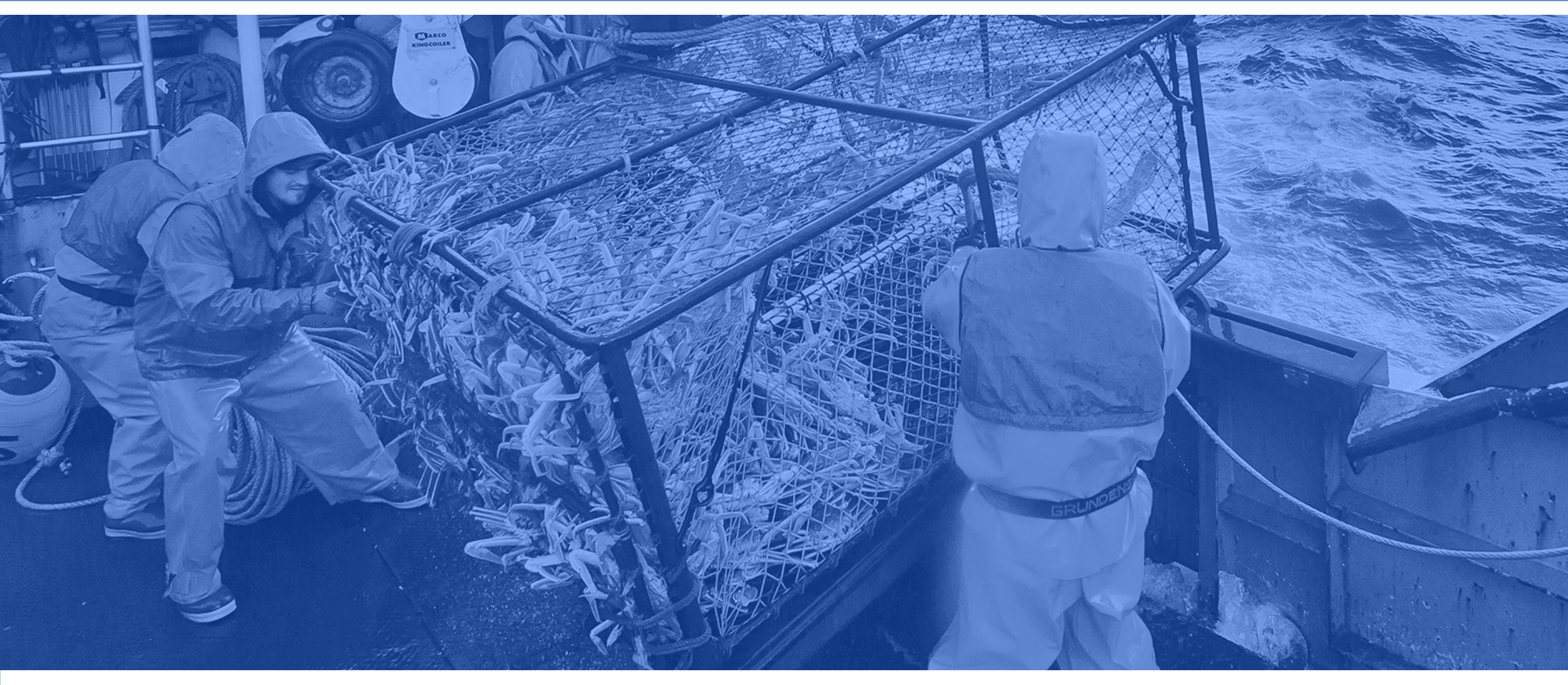

\title{
Assessment of Safety in the Bering Sea/Aleutian Island Crab Fleet
}




\section{Disclaimer}

This document is in the public domain and may be freely copied or reprinted.

Mention of any company or product does not constitute endorsement by the National Institute for Occupational Safety and Health (NIOSH). In addition, citations to Web sites external to NIOSH do not constitute NIOSH endorsement of the sponsoring organizations or their programs or products. Furthermore, NIOSH is not responsible for the content of these Web sites. All Web addresses referenced in this document were accessible as of the publication date.

\section{Ordering Information}

To receive documents or other information about occupational safety and health topics, contact NIOSH at

Telephone: 1-800-CDC-INFO (1-800-232-4636)

TTY: 1-888-232-6348

CDC INFO: $\underline{w w w . c d c . g o v / i n f o}$

or visit the NIOSH Web site at www.cdc.gov/niosh.

For a monthly update on news at NIOSH, subscribe

to NIOSH eNews by visiting www.cdc.gov/niosh/eNews.

Prepared by: Devin Lucas, PhD, Samantha Case, MPH, Theodore Teske, MA, Alexis DeLeon, BS, Dimitreus Kloczko, BFA.

\section{Suggested Citation}

NIOSH (2016). Assessment of Safety in the Bering Sea/Aleutian Island Crab Fleet.

By Lucas, D., Case, S., Teske, T., DeLeon, A., Kloczko, D., OH: U.S. Department of Health and Human Services, Centers for Disease Control and Prevention.

National Institute for Occupational Safety and Health. DHHS, (NIOSH) Publication No. 2016-112.

DHHS, (NIOSH) Publication No. 2016-112.

April 2016 


\section{INTRODUCTION}

This report provides a detailed analysis of work-related injuries and vessel safety issues within the Bering Sea/Aleutian Island (BSAI) crab fleet to identify both hazards and opportunities for safety improvements within the fleet. The BSAI crab fleet is comprised of vessels averaging 90-120 feet in length that use pot gear to harvest crab, and either process the catch on board or deliver it to on-shore or floating processors (Woodley \& Medlicott, 2001). The fishing seasons for various species of BSAI crab begin in October and typically end by May. The findings and recommendations in this report are especially relevant to the North Pacific Fishery Management Council, United States Coast Guard, and the Bering Sea/Aleutian Island crab fleet.

The BSAI crab fleet was identified as the most hazardous commercial fishery in the United States during the 1990s (Lincoln et al., 2013). During that decade, 73 crewmembers in the fleet died as a result of vessel disasters, falls overboard, or on-board injuries (Lincoln et al., 2013). Although safety regulations in place at that time required vessels to carry lifesaving equipment, such as immersion suits and life rafts, the regulations did not address the problem of overloading vessels with crab pots, a major cause of vessel disasters and deaths. This gap in safety regulations was partially corrected by the Coast Guard in 1999 with the introduction of the "At-the-Dock Stability and Safety Compliance Check" program, in which Coast Guard personnel checked crab vessels in Dutch Harbor prior to departure to ensure that each was loaded in compliance with their stability instructions. Subsequent to the introduction of this program, along with other possible factors such as changes in safety culture, the number and rate of fatalities in the fleet decreased during the period 1999-2012 (Lincoln et al., 2013; Woodley et al., 2009).

In addition to the Coast Guard Compliance Checks, the BSAI crab fishery changed in 2005 from a derby-style race for fish to a quota-based (rationalized) system. This management change contributed to an extended fishing season, smaller pot loads, and allowed for a more experienced and potentially less fatigued crew (Woodley et al., 2009). The change was also associated with a consolidation of the fishing fleet, from an average of 243 vessels during 2001-2004 to 78 vessels during 2005-2010 (North Pacific Fishery Management Council, 2010).

Fatal injuries in the BSAI crab fleet have decreased substantially through the combined and cooperative efforts of the fishing industry, Coast Guard, and National Marine Fisheries Service (NMFS). Further improvements in crewmember safety may be obtained by analyzing the causes of nonfatal injuries and vessel casualties, and developing focused interventions to address hazards. This report summarizes these hazards in the BSAI crab fleet during the 2005/06 - 2012/13 seasons. The results can be used to develop recommendations to improve safety within the fleet by the industry, Coast Guard, and fisheries management.

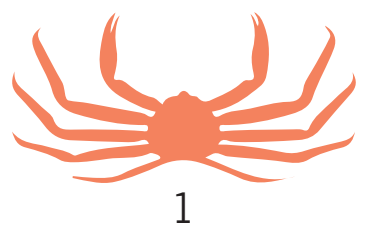




\section{Data Collection}

Vessels that operated (had permits and made landings) in the BSAI crab fishery during the 2005/06 - 2012/13 seasons were identified by NMFS and provided to NIOSH. Researchers at NIOSH reviewed Coast Guard reports of marine casualties that occurred on each identified vessel while it was operating in the crab fishery. Two types of marine casualties, personnel casualties and vessel casualties, were considered safety-related incidents and were included in this assessment.

Personnel casualties were restricted to fatal and nonfatal work-related traumatic injuries sustained by crewmembers in the fleet. Crewmember emergencies involving illnesses such as epileptic seizures or severe hypoglycemia were not included. Variables of interest included incident location, weather conditions, crewmember demographics, injury characteristics (nature, body part, source, mechanism, and severity), job task performed, and vessel characteristics (length and year built).

Vessel casualties were defined in this study as adverse events occurring to vessels that made it difficult or unsafe to continue at sea (e.g., sinking, fire, loss of propulsion, grounding, flooding). Vessel disasters are a subset of vessel casualties and were defined in this study as catastrophic incidents that forced the crews to abandon ship. Variables of interest were casualty type, severity, resolution, incident location, weather conditions, and vessel characteristics.

Because fishing vessels vary in terms of days at sea and crew size, they experience differing exposure to hazards that can result in marine casualties. A common denominator is necessary to accurately measure the risk of marine casualties in the BSAI crab fleet and enable comparison to other fishing fleets and industries. The exposure estimate used as the denominator to calculate injury rates in this study was full-time equivalent workers (FTEs), based on a standard 2000 hour work-year. FTEs adjust the worker population to reflect the same amount of exposure to risk as other workers, thereby allowing comparisons of risk between fleets and industries. Risk was expressed as the number of nonfatal injuries that occurred for every 1,000 FTEs. For vessel casualties, the exposure estimate used to measure risk was vessel-days-at-sea, expressed as the number of vessel casualties per 1,000 days at sea.

A statistical analysis was performed to explore and characterize the data. The analysis was complicated by the presence of missing data caused by the varying level of detail contained in the source documents (Coast Guard investigation reports). When calculating percent distributions, missing data were excluded from the denominators. Since each case could have missing data on different variables, the denominator fluctuated for the calculation of each variable's percent distribution. In the following results section, when presenting the percent distribution for each variable, the denominator for that variable is shown for the first calculated percentage and then suppressed for subsequent calculations using the same denominator. 


\section{Results: Personnel Casualites}

Between 2005/06 and 2012/13, 65 injuries in the BSAI crab fleet were reported to the Coast Guard, of which one was fatal (Figure 1). The remaining 64 injuries were nonfatal, ranging in severity from minor to severe, with severity of two nonfatal cases missing (See Appendix B for injury severity coding rules and examples). Many of these nonfatal injuries were classified as minor $(27 / 62,44 \%)$ or moderate $(22,35 \%)$. Twelve injuries (19\%) were classified as serious, and one crewmember sustained a severe injury (See Appendix C for descriptions of these 13 serious/ severe injuries). No critical injuries were reported during the study period.

Figure 1 - Severity of fatal and nonfatal injuries, BSAI crab fleet, 2005/06 - 2012/13 ( $n=63$, missing data for two cases).

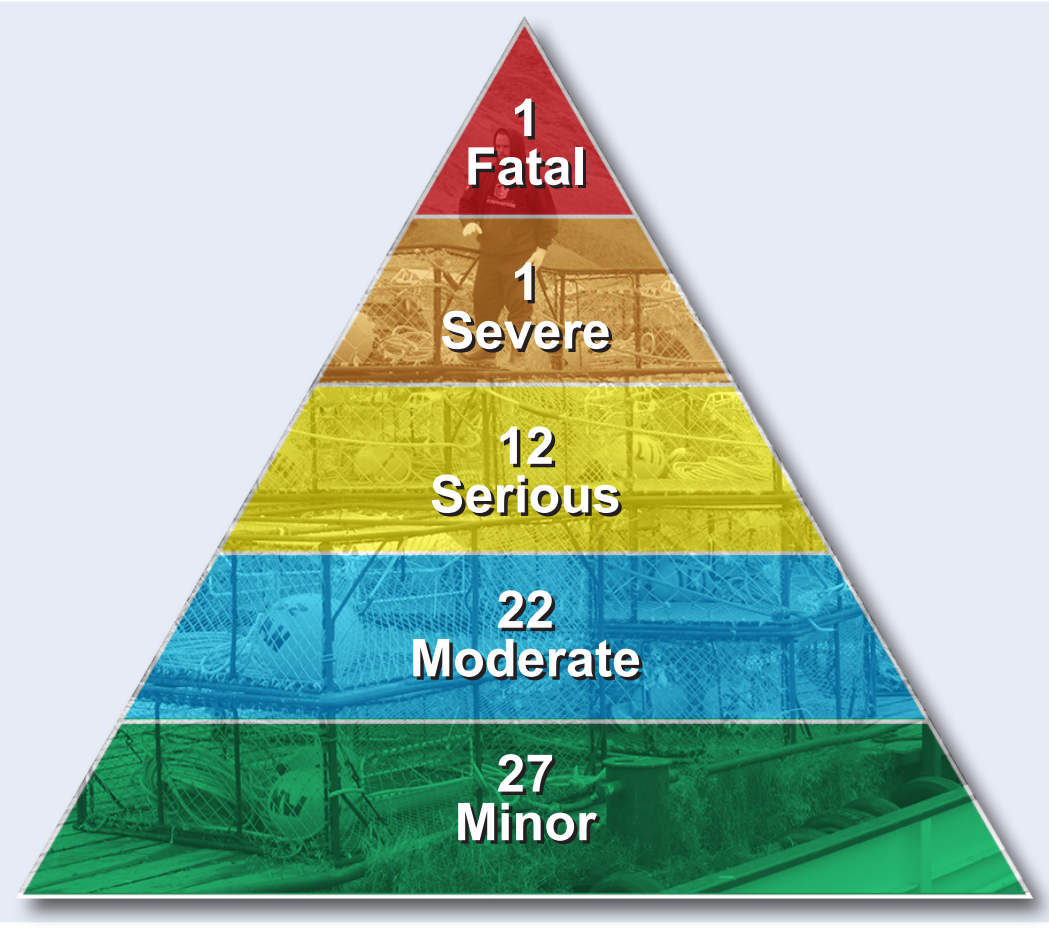

\section{Fatal Injuries}

During 2005/06 - 2012/13, one fatality occurred in the fleet. In January 2009, crewmembers were setting pots when a deckhand, who had been throwing a line, inadvertently stepped into a coil of line. The line quickly tightened around his lower leg as a pot was launched and pulled him overboard. Personal flotation devices (PFDs) are not federally mandated to be worn by crewmembers in the fishing industry, and the crewmember in this incident was not wearing a PFD when he was pulled overboard. The crew immediately began man overboard procedures, including maneuvering the vessel to maintain a visual on the entry location, and contacting the Coast Guard for search and rescue assistance. Despite their efforts, the crewmember was never recovered from the water. 


\section{Nonfatal Injuries}

During 2005/06 - 2012/13, 64 nonfatal injuries were reportedly sustained by BSAI crab crewmembers. The rate of nonfatal injury for this period was 12 injuries per 1,000 FTEs. Most of the injuries occurred to deckhands (39/50,78\%), followed by processors $(7,14 \%)$, and engineers $(3,6 \%)$. One mate was injured. All injured crewmembers were male, and the median age was 33 years (21-58 years) with a median of four years fishing experience (0-25 years). Most resided in Washington (16/57, 28\%), Alaska (12, 21\%), and Oregon (11, 19\%).

Fractures were the most frequently reported injury (12/57, 21\%), of which half (6) occurred while crewmembers were handling gear on deck. Fractures also occurred while crewmembers were setting or hauling gear. Other commonly reported injuries included contusions $(11,19 \%)$, lacerations $(10,18 \%)$, and sprains, strains, and tears $(8,14 \%)$. Most injuries occurred to the upper extremities $(24 / 63,38 \%)$, followed by lower extremities $(16,25 \%)$, trunk $(15,24 \%)$, and head $(8,13 \%)$. Fractures and lacerations were the most common types of injuries affecting upper extremities, and sprains/strains/tears were the most common injuries affecting lower extremities (Figure 2). While most injuries were classified as minor or moderate in severity, fractures, internal injuries, and amputations were more likely to be serious or severe (Figure 3).

Figure 2 - Types of nonfatal injuries, BSAI crab fleet, 2005/06 - 2012/13 ( $n=56$, missing data on either body part or type of injury for 8 cases).

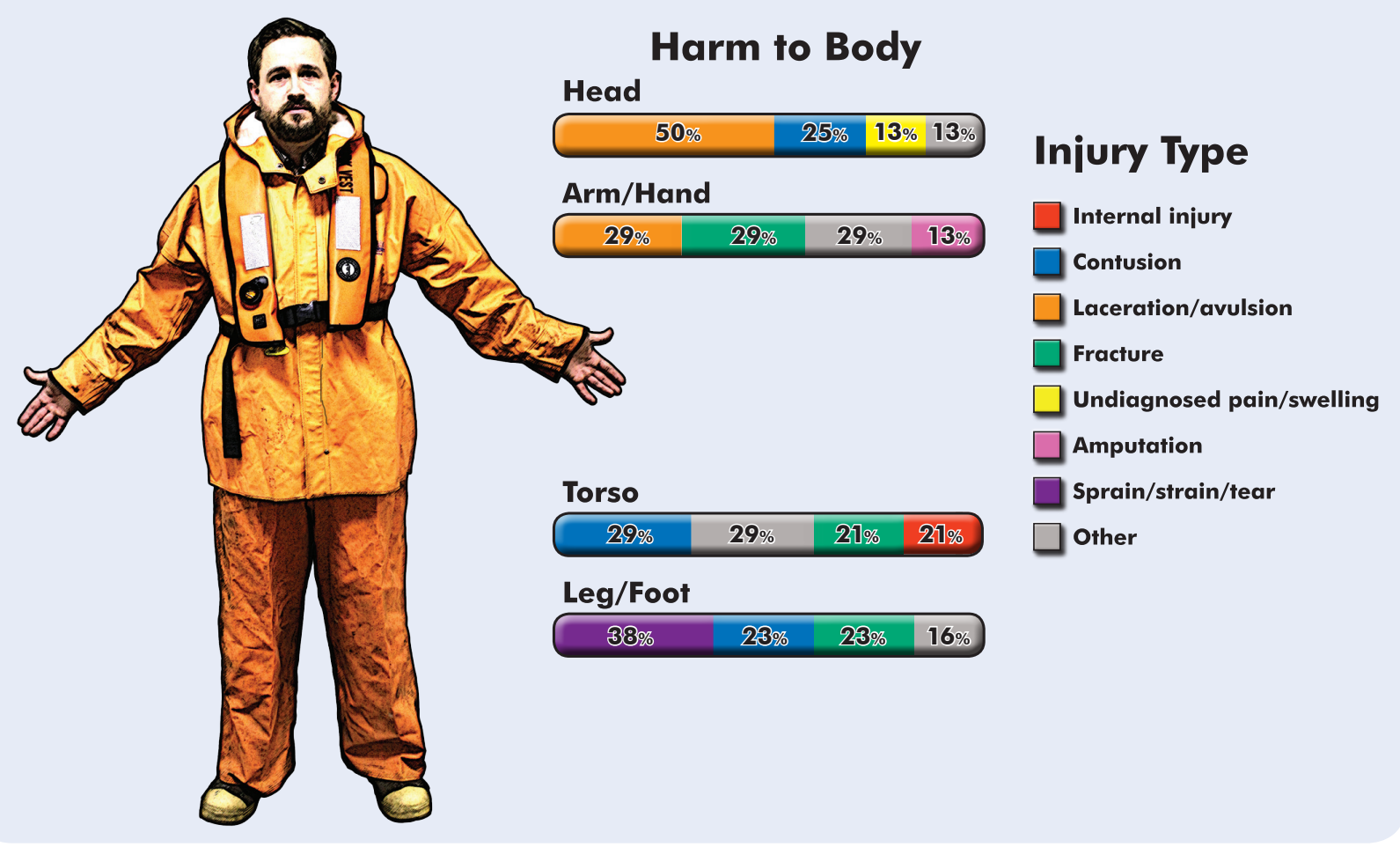


Figure 3 - Types and severity of nonfatal injuries, BSAI crab fleet, 2005/06 - 2012/13 ( $n=57$, missing data on either type of injury or severity for 7 cases).

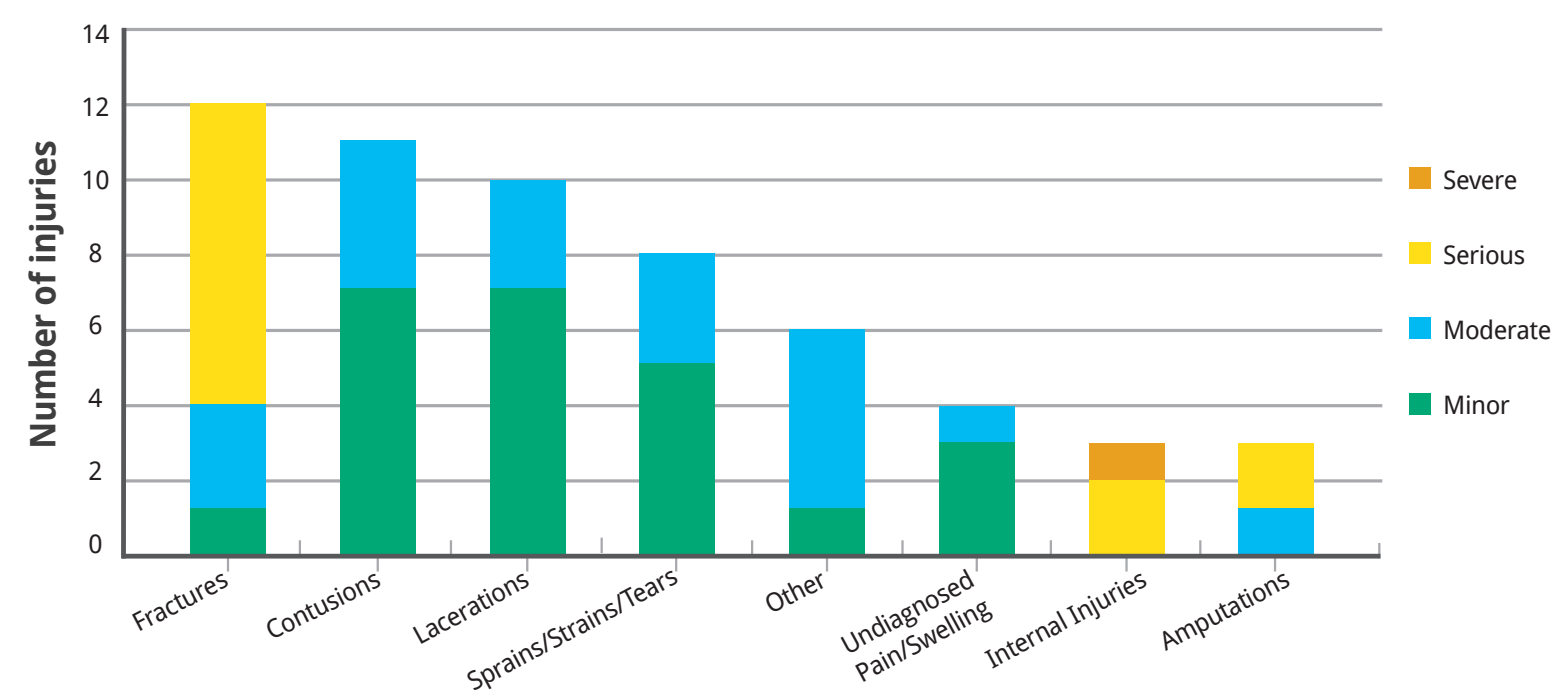

Injuries most often occurred while crewmembers were handling gear on deck, setting the gear, hauling the gear, and handling the catch (Figure 4). Contact with objects and equipment during these and other job tasks resulted in the most injuries $(35 / 55,64 \%)$. Contact with crab pots in particular made up the largest proportion of those injuries $(15 / 35,43 \%)$, often from crewmembers being struck by moving or falling crab pots, or being struck against pots. The single severe injury in the study period occurred when a pot fell onto a crewmember while he was untying pots. Slips, trips, and falls were the next leading cause of nonfatal injuries, resulting in 11 injuries (20\%). Slips, trips, and falls occurred during almost all of the job tasks (Figure 4).

Figure 4 - Job tasks and events causing nonfatal injuries, BSAI crab fleet, 2005/06-2012/13 ( $n=55$, missing data on either job task or event for 9 cases).

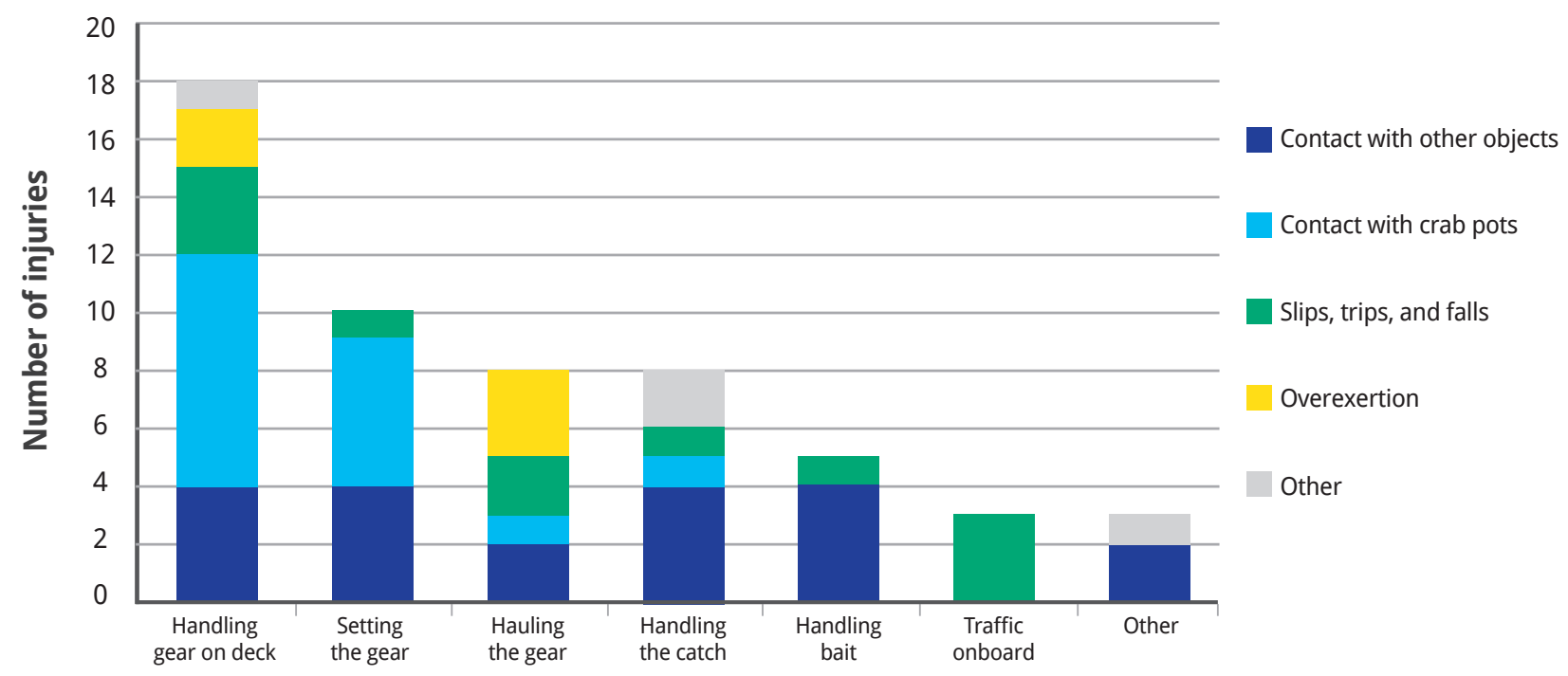




\section{ResulT: VesSel CAsualites}

During 2005/06 - 2012/13, 34 vessel casualties were reported in the BSAI crab fleet, resulting in a rate of 7.9 casualties per 1,000 days at sea. Minor vessel casualties, defined as those completely resolved at sea by the crew, accounted for $26 \%$ (9) of all casualties. Nearly half of the vessel casualties were classified as moderate $(16,47 \%)$, meaning that the problem was either resolved at sea with outside assistance, or the vessel returned to port under its own power for repairs. Nine incidents (26\%) were classified as serious casualties, meaning the vessel had to be rescued at sea and towed to port for repairs (See Appendix D for descriptions of these nine serious vessel casualties). There were no vessel disasters (e.g., sinking, capsizing) during the study period.

Figure 5 - Illustration of vessel casualty severity, BSAI crab fleet, 2005/06 - 2012/13 ( $n=34)$.

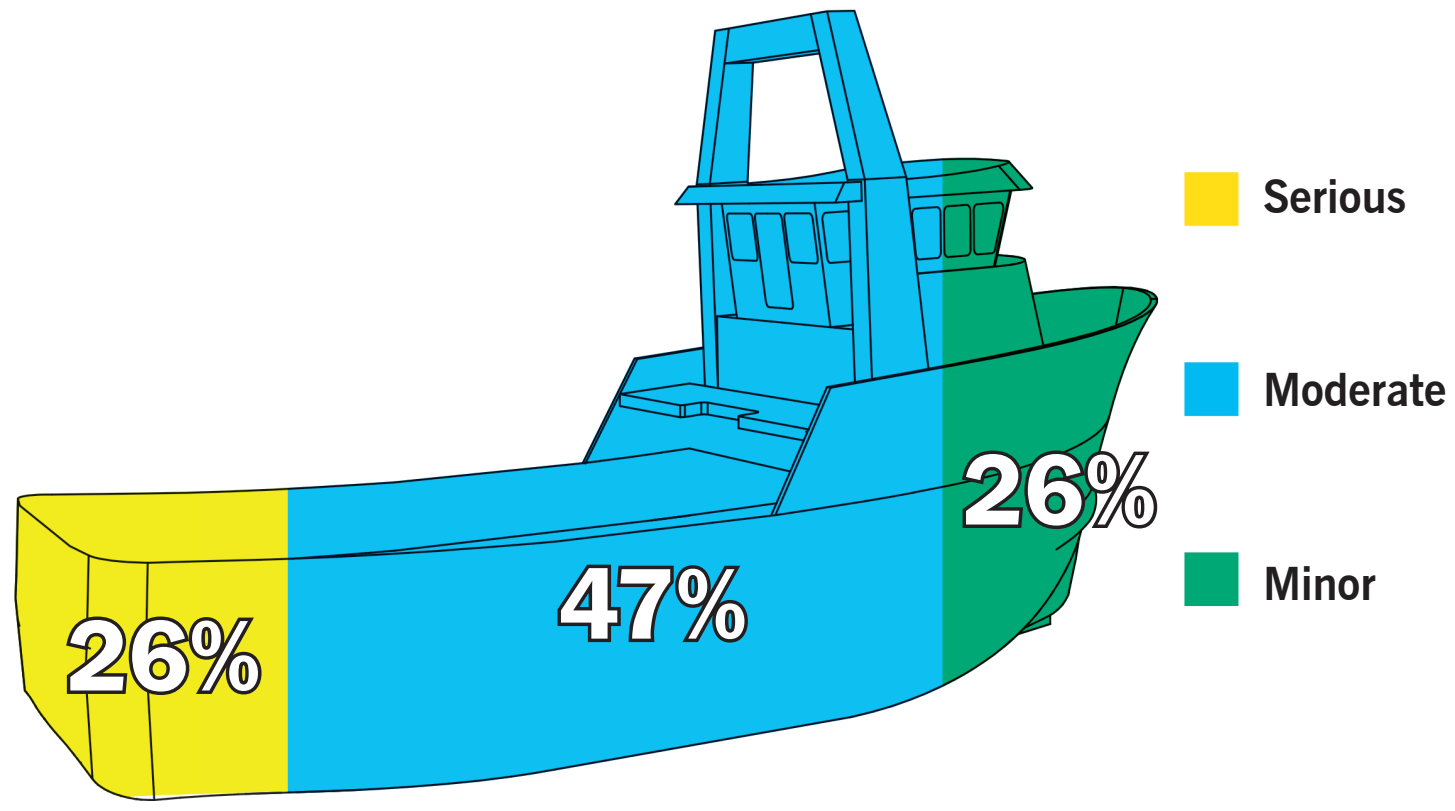

The most frequently reported casualties involved loss of propulsion $(13,38 \%)$, followed by groundings $(6,18 \%)$ and collisions $(4,12 \%)$. The majority of incidents in which the vessel lost propulsion were classified as moderate (6) or serious (5) (Figure 6). While collisions and groundings were similar in frequency, the severity of the casualty differed between the two types. Collisions were mostly minor, while groundings were mostly serious. Flooding and fire events were all classified as moderate in severity, but the two loss of steering incidents were classified as serious.

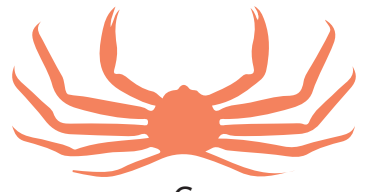


Figure 6 - Type and severity of vessel casualties, BSAI crab fleet, 2005/06 - 2012/13 ( $n=34)$.
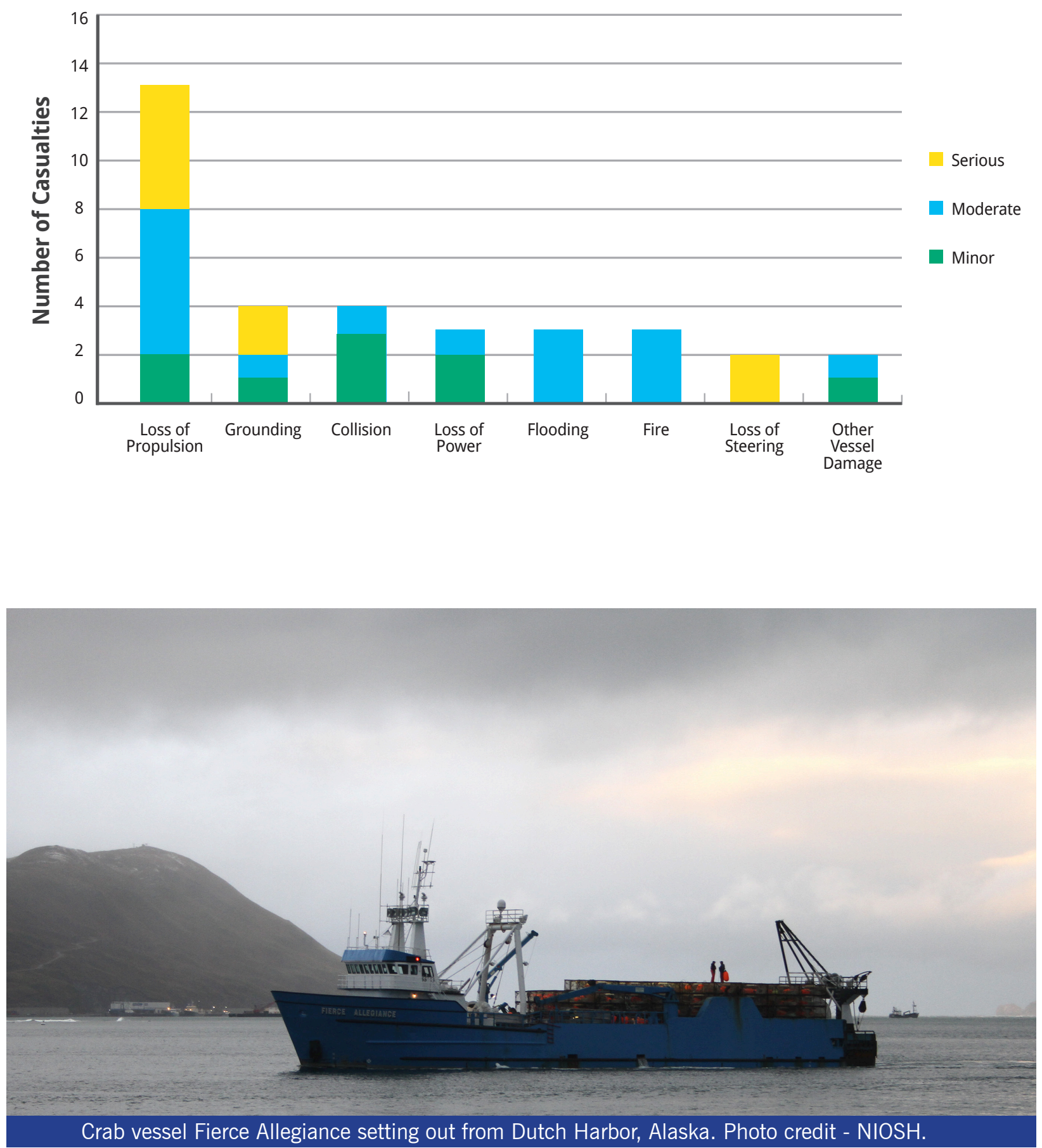


\section{Safety Trends and Recommendations}

\section{Fatalities}

In the 1990s, the BSAI crab fleet averaged eight fatalities per year; since 2000 after the implementation of the "At-the-Dock Stability and Safety Compliance Check" program and crab rationalization, there has been less than one fatality per year on average (Figure 7). Taking into account reductions in the number of vessels and crewmembers, this represents more than a $60 \%$ decline in the risk of fatal injuries (Lincoln \& Lucas, 2010). The stability safety program should continue to be administered by the Coast Guard prior to each crab season. In addition, vessel owners and operators should periodically consult a naval architect to refresh knowledge of safe loading limits and adhere to stability instructions (USCG, 2010).

The single fatality in the fleet during the study time period (2005/06 - 2012/13) was due to a fall overboard. This loss of life is a tragic reminder that deadly hazards still exist in the fishery, even as the overall risk of fatalities in the fleet has declined significantly (Woodley et al., 2009). To prevent further deaths from falls overboard, all crewmembers should wear a PFD at all times on deck, as well as a readily accessible knife to cut lines in an emergency (NIOSH, 2010). Effective manoverboard training and drills should be conducted every month (USCG, 2015). As a supplement to the currently required life ring, vessel operators should add more effective recovery devices and utilize the devices during monthly man overboard drills (USCG, 2015).

Figure 7 - Fatalities by season and incident type, BSAI crab fleet, 1991/92 - 2012/13 ( $n=82$ ). Data sources: for 1990-2009 (Lincoln et al., 2013); for 2010-2013 (NIOSH Commercial Fishing Incident Database, 2014).

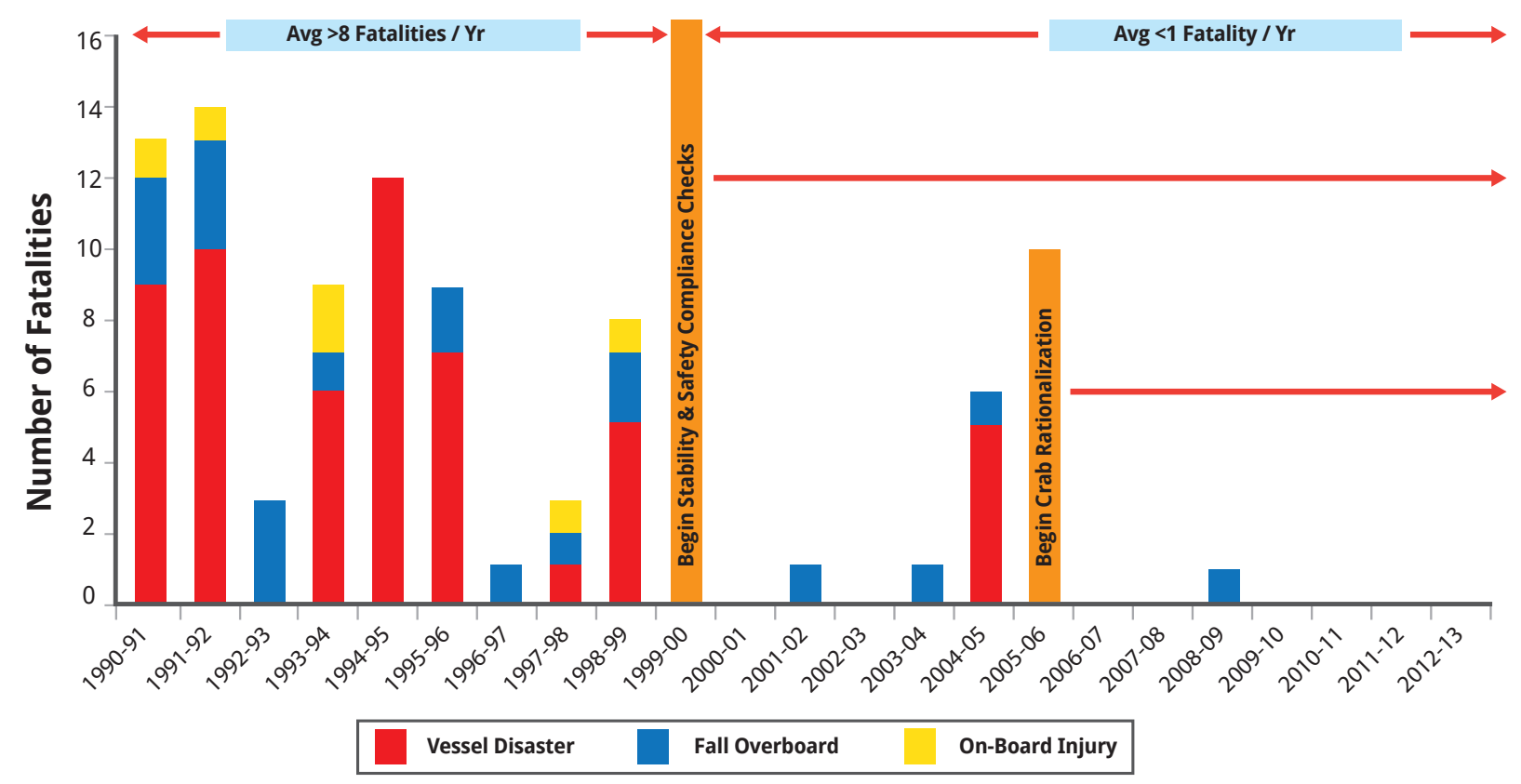




\section{Nonfatal Injuries}

An average of eight nonfatal injuries among crewmembers were reported to the Coast Guard annually during the study period. The number of nonfatal injuries is too small to perform a statistical analysis of the trend over time, but a visual examination of the trend indicates that aside from small yearly fluctuations, the annual number of injuries remained relatively unchanged during the study period (Figure 8). It is unclear how accurately the number of reported injuries represents the true injury burden in the fleet. Underreporting of injuries is likely a problem, but the extent has not been determined. Companies that operate fishing vessels are required to report to the Coast Guard any "injury that requires professional medical treatment (treatment beyond first aid) and, if the person is engaged or employed on board a vessel in commercial service, that renders the individual unfit to perform his or her routine duties" (Code of Federal Regulations, Title 46, Section $4.05-1$ ). Enhanced reporting by fishermen and thorough documentation by the Coast Guard would improve data quality. Measures to improve reporting of injuries should be considered by vessel owners and the Coast Guard.

The annual risk of nonfatal injuries in the BSAI crab fleet was 12 per 1,000 FTEs. There are very few studies in the literature that have similarly estimated the risk of nonfatal injuries in fishing fleets, hampering the comparison of risk between fleets. One recent study of nonfatal injuries in the BSAI freezer-longline and freezer-trawl fleets found rates of 35 and 43 injuries per 1,000 FTEs, respectively (Lucas et al., 2014). In 2014, the risk of nonfatal injuries in all U.S. private industries was estimated at 32 per 1,000 FTEs (BLS, 2015). The most likely explanation for the seemingly low risk of nonfatal injuries in the BSAI crab fleet is underreporting of injuries, thereby artificially deflating the true risk.

The large proportion of nonfatal injuries caused by crab pots highlights the hazard of unrestrained and moving pots. Vessel motion can cause unsecured pots to move abruptly, striking crewmembers on deck. Ensuring that pots are secured when not in use can help to prevent this from occurring. Normal operations with pots (e.g., stacking or launching pots) can also be hazardous. Because of their size and weight, even minor mistakes while handling or working near pots can lead to fractures, amputations, and other serious injuries. Procedures for securing and moving pots should be reviewed and adjusted by skippers and crewmembers to decrease the risk of crewmembers being struck by pots. All crewmembers should receive training on safe work practices and be vigilant and aware of their surroundings while working on deck.

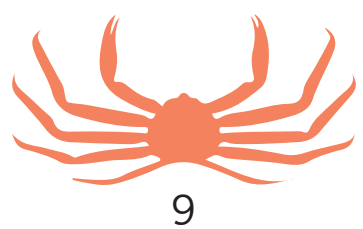


To prevent injuries caused by slips, trips, and falls, inspect the deck and other walking surfaces periodically to identify and eliminate slippery areas. Non-skid gratings, fiber mats, and nonslip coatings can be used to reduce slip hazards. Serious injuries were reported that involved unguarded or inadequately guarded machinery. Vessel operators should inspect guards on machinery, including bait choppers, cranes, and winches, and repair or replace deficient or missing guards. Keep all vessel equipment maintained regularly per manufacturers' guidelines.

Figure 8 - Rates of vessel casualties and nonfatal injuries by season, BSAI crab fleet, 2005/06 - 2012/13

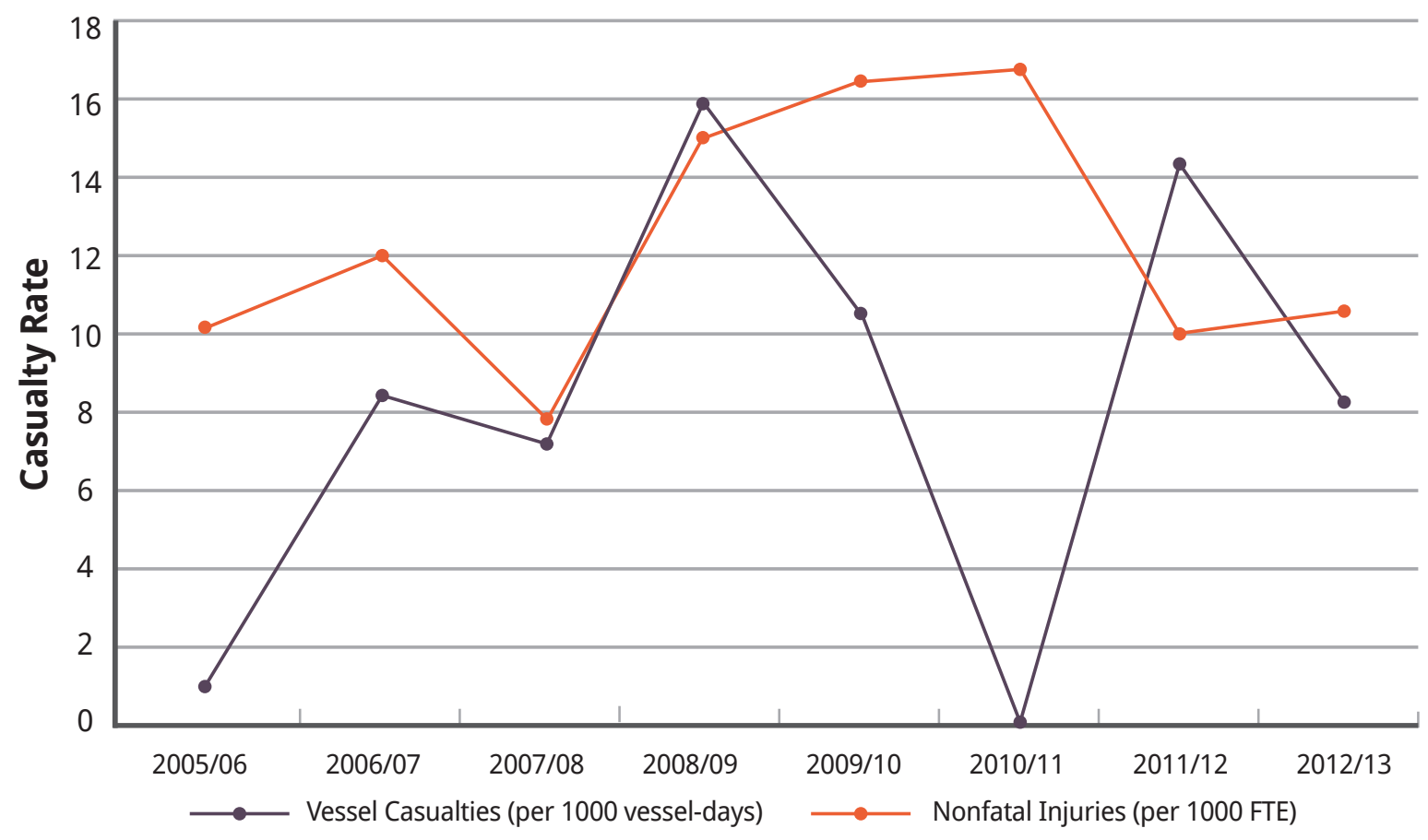

\section{Vessel Casualties}

Although there were no vessel disasters during 2005/06 - 2012/13, vessels should continue to carry functional lifesaving equipment on board at all times and to regularly conduct emergency drills such as vessel abandonment, to familiarize crewmembers with the equipment. All crewmembers should take an 8-hour marine safety class at least every five years to maintain the skills needed in an emergency (USCG, 2015).

The frequency of vessel casualties that were reported to the Coast Guard was highly variable during the study period, with a high of eight casualties during one season, and a low of zero during another

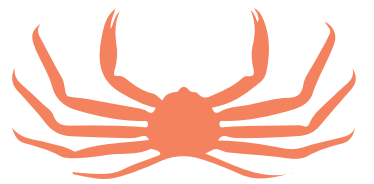


season. There was no discernable trend in the rate of reported vessel casualties (Figure 8). Similar to nonfatal injuries, vessel casualties were likely underreported, especially those that did not involve assistance from the Coast Guard. Measures to improve reporting of vessel casualties should be considered by vessel owners and the Coast Guard.

Vessel casualties such as loss of propulsion can result in delayed or shortened fishing trips, which decrease productivity and profits. They may also lead to more serious events, including vessel disasters. Ensuring regular maintenance, particularly on propulsion systems, may help to reduce the risk of vessel casualties or disasters at sea. Vessel owners and operators should consider reviewing and updating their maintenance procedures for propulsion and other critical systems to improve the reliability of those systems at sea (USCG, 2015).

\section{CONCLUSION}

Coast Guard programs, industry initiatives, and fishery management changes have improved crewmember safety in the BSAI crab fleet. Although fewer fatalities have occurred, these fisheries do take place in a harsh environment, in the winter, in remote locations on uninspected vessels, sometimes transiting through ice. Efforts to prevent nonfatal injuries, fatalities, and vessel casualties should be continued by considering the recommendations in this report. In addition, during the development of an Alternate Safety Compliance Program for the BSAI crab fleet, industry representatives should review the findings in this report with the U.S. Coast Guard to determine if other good marine practices outlined in the Alternate Safety Compliance Program Draft Matrix of Possible Requirements (USCG, 2015) should be adopted.

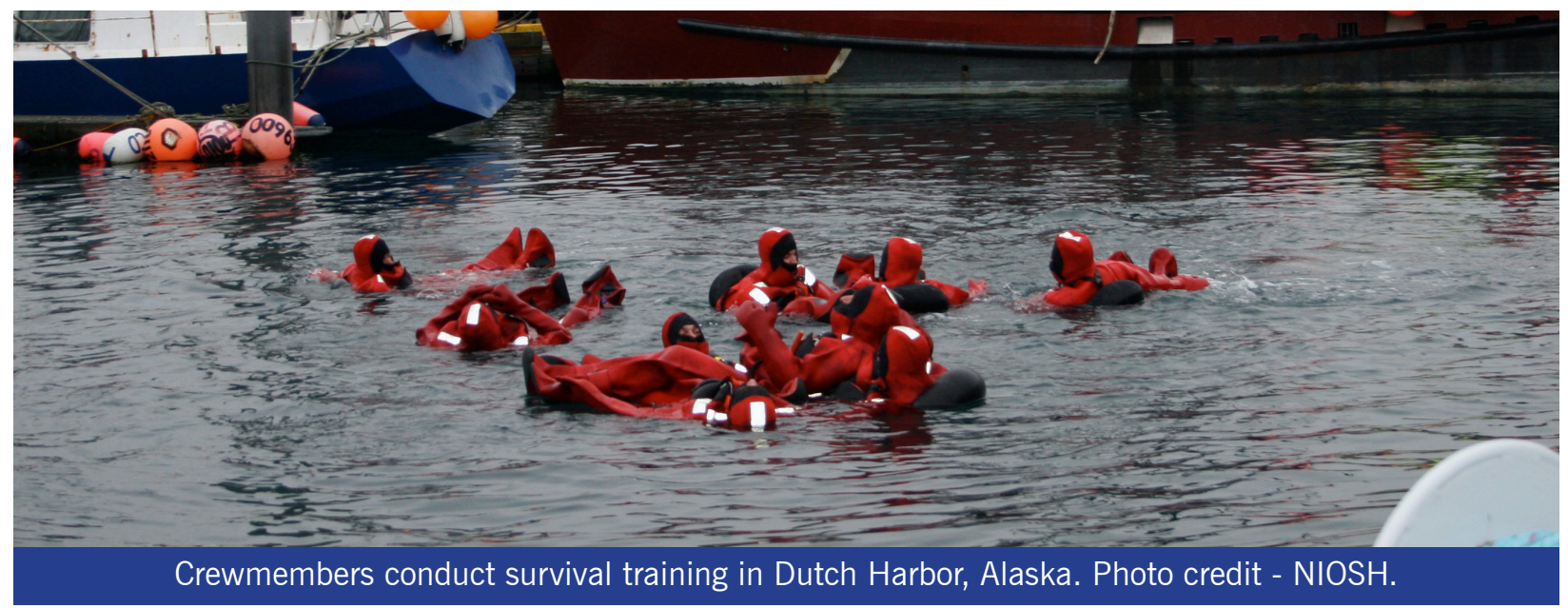




\begin{tabular}{|c|c|}
\hline \multicolumn{2}{|c|}{$\begin{array}{l}\text { Appendix A: Recommendations for Reducing Hazards }{ }^{\star} \text { in the BSAI Crab Fleet } \\
\text { (NIOSH, 1997; NIOSH, 2010; USCG, 2010; USCG, 2015) }\end{array}$} \\
\hline Vessel Casualties & $\begin{array}{l}\text { To prevent vessel disasters and other serious vessel casualties: } \\
\text { 1. Participate in the USCG "At-the-Dock Stability and Safety } \\
\text { Compliance Check" program prior to each crab season. } \\
\text { 2. Periodically consult a naval architect to refresh knowledge of safe } \\
\text { loading limits and adhere to stability instructions. } \\
\text { 3. Update and formalize maintenance procedures for propulsion, } \\
\text { power, steering, and other critical systems, and closely follow the } \\
\text { established schedule. } \\
\text { 4. All crewmembers should take an 8-hour marine safety class at } \\
\text { least every five years to maintain the skills needed in an emergency. } \\
\text { 5. Review the findings in this report with the U.S. Coast Guard to } \\
\text { determine if other good marine practices outlined in the Alternate } \\
\text { Safety Compliance Program Draft Matrix of Possible Requirements } \\
\text { should be adopted to prevent vessel casualties. }\end{array}$ \\
\hline Falls Overboard & $\begin{array}{l}\text { To prevent fatal falls overboard: } \\
\text { 1. Create or update PFD policies to require all crewmembers to wear PFDs } \\
\text { at all times while on deck. } \\
\text { 2. Increase the effectiveness of man overboard training and drills.. } \\
\text { 3. Add effective recovery devices and utilize the devices during monthly } \\
\text { man overboard drills. } \\
\text { 4. Review the findings in this report with the U.S. Coast Guard to determine } \\
\text { if other good marine practices outlined in the Alternate Safety } \\
\text { Compliance Program Draft Matrix of Possible Requirements should be } \\
\text { adopted to prevent falls overboard. }\end{array}$ \\
\hline Onboard Injuries & $\begin{array}{l}\text { To prevent injuries sustained onboard the vessel: } \\
\text { 1. Review and adjust procedures for securing and moving pots. } \\
\text { 2. Conduct periodic training with crewmembers on deck safety. } \\
\text { 3. Inspect the deck and other walking surfaces to identify and eliminate } \\
\text { slippery areas. } \\
\text { 4. Inspect guards on machinery including bait choppers, cranes, and } \\
\text { winches; and repair or replace deficient or missing guards. } \\
\text { 5. Keep all vessel equipment maintained regularly per } \\
\text { manufacturers' guidelines. }\end{array}$ \\
\hline
\end{tabular}

*In addition to existing fishing industry safety regulations.

**Recommendations are based on a review of specific hazards for the BSAI crab fleet during the study period, and reflect previously published NIOSH recommendations for other commercial fishing fleets.

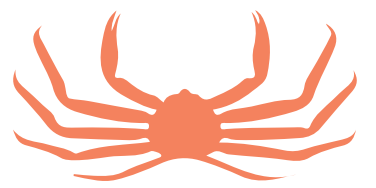




\begin{tabular}{|l|l|l|}
\hline Appendix B. Injury Severity Scale (USCG, 2012) \\
\hline Minor & $\begin{array}{l}\text { The injury is minor or superficial. } \\
\text { No medical treatment was } \\
\text { required. }\end{array}$ & $\begin{array}{l}\text { Examples: Minor /superficial scrapes } \\
\text { (abrasions); minor bruises; minor cuts; digit } \\
\text { sprain; first degree burn; minor head trauma } \\
\text { with headache or dizziness; minor } \\
\text { sprain/strain. }\end{array}$ \\
\hline Moderate & $\begin{array}{l}\text { The injury exceeds the minor } \\
\text { level, but did not result in broken } \\
\text { bones (other than fingers, toes, } \\
\text { or nose) loss of limbs, severe } \\
\text { hemorrhaging, muscle, nerve, } \\
\text { tendon, or internal organ damage. } \\
\text { Professional medical treatment } \\
\text { may have been required. If so the } \\
\text { person was not hospitalized for } \\
\text { more than 48 hours within 5 days } \\
\text { of the injury. }\end{array}$ & $\begin{array}{l}\text { Examples: broken fingers, toes, or nose, } \\
\text { amputated fingers or toes; degloving of fingers } \\
\text { or toes; dislocated joint; severe strain/sprain; } \\
\text { second or third degree burn covering 10\% or } \\
\text { less of the body (if face is included move up } \\
\text { one category); herniated disc. }\end{array}$ \\
\hline Serious & $\begin{array}{l}\text { The injury exceeds the moderate } \\
\text { level and requires significant } \\
\text { medical/surgical management. } \\
\text { The person was not hospitalized } \\
\text { for more than 48 hours within } \\
5 \text { days of the injury. }\end{array}$ & $\begin{array}{l}\text { Examples: broken bones (other than fingers, } \\
\text { toes, or nose); partial loss of limb (amputation } \\
\text { below elbow/knee); degloving of the entire } \\
\text { hand/arm or foot/leg; second or third degree } \\
\text { burns covering 20-30\% of the body (if face } \\
\text { included move up one category); bruised } \\
\text { organs. }\end{array}$ \\
\hline Severe & $\begin{array}{l}\text { The injury exceeds the moderate } \\
\text { level and requires significant } \\
\text { medical/ surgical management. } \\
\text { The person was hospitalized for } \\
\text { more than } 48 \text { hours within } 5 \text { days } \\
\text { of the injury and, if in intensive } \\
\text { care, was in for less than 48 hours. }\end{array}$ & $\begin{array}{l}\text { Examples: Internal hemorrhage; punctured } \\
\text { organs; severed blood vessels; second/third } \\
\text { degree burns covering 30-40\% of the body (if } \\
\text { face included, move up one category), loss of } \\
\text { entire limb (amputation of whole arm/leg). }\end{array}$ \\
\hline
\end{tabular}

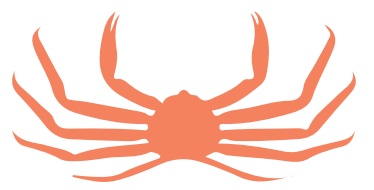




\begin{tabular}{|c|c|}
\hline \multicolumn{2}{|c|}{ Appendix C. Descriptions of Serious/Severe Injuries, BSAI Crab Fleet, 2005/06 - 2012/13 } \\
\hline Year of Incident & Description of Injury Event (13 Serious/Severe Injuries) \\
\hline \multicolumn{2}{|r|}{ Setting the Gear } \\
\hline 2009 & $\begin{array}{l}\text { A crewmember sustained internal injuries when he was struck by a falling } \\
\text { crab pot he had just untied. }\end{array}$ \\
\hline 2009 & $\begin{array}{l}\text { A crewmember was untying a crab pot when it fell on him after the vessel } \\
\text { rolled, resulting in a broken back. }\end{array}$ \\
\hline 2013 & A crewmember sustained a fractured lower leg while setting gear. \\
\hline \multicolumn{2}{|r|}{ Hauling the Gear } \\
\hline 2013 & $\begin{array}{l}\text { A crewmember was pulling crab pots from the water when he slipped and } \\
\text { fell, breaking his collar bone. }\end{array}$ \\
\hline \multicolumn{2}{|r|}{ Handling Gear on Deck } \\
\hline 2005 & $\begin{array}{l}\text { A mate was holding onto a pot when the crane operator winched up. As the } \\
\text { pot swung to the side, the crewmember fell, injuring his left shoulder. }\end{array}$ \\
\hline 2005 & $\begin{array}{l}\text { A crewmember operating the crane to offload crab lowered the crane boom } \\
\text { down on his hand, resulting in an amputation of his right hand at the wrist. }\end{array}$ \\
\hline 2009 & $\begin{array}{l}\text { A crewmember was struck by a wave and thrown into pots, resulting in } \\
\text { fractured ribs and abrasions. }\end{array}$ \\
\hline 2010 & $\begin{array}{l}\text { A crewmember's hand was jammed against a crab pot while stacking pots } \\
\text { resulting in a fracture, after the vessel rolled to the side. }\end{array}$ \\
\hline 2010 & $\begin{array}{l}\text { A crewmember was repairing a crab pot on deck while lying on his back. } \\
\text { The vessel rolled and he slid across the deck, striking the right side of his } \\
\text { body against the vessel. }\end{array}$ \\
\hline 2010 & $\begin{array}{l}\text { An engineer was attempting to repair a pot when he became pinched } \\
\text { between pots and sustained cracked ribs and punctured lungs. }\end{array}$ \\
\hline \multicolumn{2}{|r|}{ Handling the Catch } \\
\hline 2005 & $\begin{array}{l}\text { A crewmember slipped and fell off of the sorting table while sorting crab, } \\
\text { breaking his ankle. }\end{array}$ \\
\hline 2013 & $\begin{array}{l}\text { A crewmember was struck by an unsecured crab pot after the vessel rolled, } \\
\text { resulting in a fractured leg. }\end{array}$ \\
\hline \multicolumn{2}{|r|}{ Handling Bait } \\
\hline 2005 & $\begin{array}{l}\text { A crewmember was cleaning the bait chopper when he inadvertently turned } \\
\text { on the equipment. His left hand became caught in the chopper, resulting in } \\
\text { an amputation below his wrist. }\end{array}$ \\
\hline
\end{tabular}




\begin{tabular}{|l|l|}
\hline \multicolumn{2}{|l|}{ Appendix D. Descriptions of Serious Vessel Casualties, BSAI Crab Fleet, 2005/06 - 2012/13 } \\
\hline Year of Incident & \multicolumn{1}{|c|}{ Description of Event (9 Serious Vessel Casualties) } \\
\hline 2008 & $\begin{array}{l}\text { A vessel experienced steering failure after the weld between the rudder and } \\
\text { flange broke. The vessel was towed to port by another fishing vessel } \\
\text { for repairs. }\end{array}$ \\
\hline 2008 & $\begin{array}{l}\text { A vessel's oil cooler ruptured, prompting a shutdown of the engines. The crew } \\
\text { attempted to change the oil cooler at sea but were unsuccessful. The vessel } \\
\text { was towed to port by an unspecified vessel. }\end{array}$ \\
\hline 2009 & $\begin{array}{l}\text { A vessel experienced a partial loss of propulsion and proceeded to return to } \\
\text { port. While en route, the vessel lost all propulsion. The vessel was towed to } \\
\text { port by another fishing vessel. }\end{array}$ \\
\hline 2009 & $\begin{array}{l}\text { A vessel's engine died after the fuel pressure dropped. The vessel was towed to } \\
\text { port for repairs by an unspecified vessel. }\end{array}$ \\
\hline 2010 & $\begin{array}{l}\text { A vessel ran aground during transit and was unable to back off the rocks. A } \\
\text { tug assisted the vessel and towed it back to port. }\end{array}$ \\
\hline 2012 & $\begin{array}{l}\text { A vessel, having just completed routine maintenance, was in transit away } \\
\text { from port when the engine died. The vessel was towed back to port by a } \\
\text { nearby unspecified vessel. }\end{array}$ \\
\hline 2012 & $\begin{array}{l}\text { A vessel ran aground after experiencing radar software errors and low } \\
\text { visibility. The vessel was towed to port by a tug. }\end{array}$ \\
\hline 2013 & $\begin{array}{l}\text { A vessel's rudder post broke due to metal fatigue, resulting in a loss of } \\
\text { steering. The vessel was towed to port for repairs by another fishing vessel. }\end{array}$ \\
\hline $\begin{array}{l}\text { A vessel experienced loss of propulsion due to water in the fuel, prompting a } \\
\text { shutdown of the engines. The vessel was towed to port by another } \\
\text { fishing vessel. }\end{array}$ \\
\hline
\end{tabular}

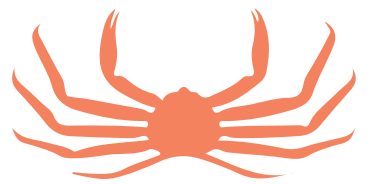




\section{REFERENCES}

BLS. (2015). Employer-Reported Workplace Injuries and illnesses - 2014. (USDL-15-2086). Washington, DC: Bureau of Labor Statistics.

Lincoln, J. M., \& Lucas, D. L. (2010). Occupational fatalities in the United States commercial fishing industry, 2000-2009. J Agromedicine, 15(4), 343-350.

Lincoln, J. M., O’Connor, M. B., Retzer, K. D., Hill, R. D., Teske, T. D., Woodward, C. C., . . Conway, G. A. (2013). Occupational fatalities in Alaska: two decades of progress, 1990-1999 and 2000-2009. J Safety Res, $44,105-110$.

Lucas, D. L., Kincl, L. D., Bovbjerg, V. E., Lincoln, J. M., \& Branscum, A. J. (2014). Work-Related Traumatic Injuries Onboard Freezer-Trawlers and Freezer-Longliners Operating in Alaskan Waters during 20012012. Am J Ind Med, 57, 826-836.

NIOSH. (1997). Current Intelligence Bulletin 58: Commercial Fishing Fatalities in Alaska Risk Factors and Prevention Strategies. By Lincoln JM and Conway GA. Anchorage, AK: U.S. Department of Health and Human Services, Centers for Disease Control and Prevention, National Institute for Occupational Safety and Health, DHSS (NIOSH) Publication No. 97-163.

NIOSH. (2010). Fatal Occupational Injuries in the U.S. Commercial Fishing Industry: Risk Factors and Recommendations, Alaska region. By Lincoln JM and Lucas DL. Anchorage, AK: U.S. Department of Health and Human Services, Centers for Disease Control and Prevention, National Institute for Occupational Safety and Health, DHSS (NIOSH) Publication No. 2011-103.

North Pacific Fishery Management Council. (2010). Five-Year Review of the Crab Rationalization Management Program for Bering Sea and Aleutian Islands Crab Fisheries. Retrieved from http://www. npfmc.org/wp-content/PDFdocuments/catch shares/Crab/5YearRev1210.pdf.

USCG. (2010). Stability practices for Alaskan commercial fishermen. Juneau, AK: United States Coast Guard. Safety Alert 01-10.

USCG. (2012). Marine Information for Safety and Law Enforcement. Washington, DC: United States Coast Guard.

USCG. (2015). Alternate Safety Compliance Program Draft Matrix of Possible Requirements. Retrieved from http://www.uscg.mil/d13/cfvs/PDFs/ASCP MatrixDraft $10 \quad 30 \quad 20 \quad$ 15.pdf.

Woodley, C. J., Lincoln, J. M., \& Medlicott, C. J. (2009). Improving Commercial Fishing Safety Through Collaboration. Proceedings of the Marine Safety and Security Council, 66, 38-46.

Woodley, C. J., \& Medlicott, C. J. (2001). A Review of an "At the Dock" Stability \& Pot Loading Survey. Proceedings of the Marine Safety Council, 58(2), 40-43. 
政: 

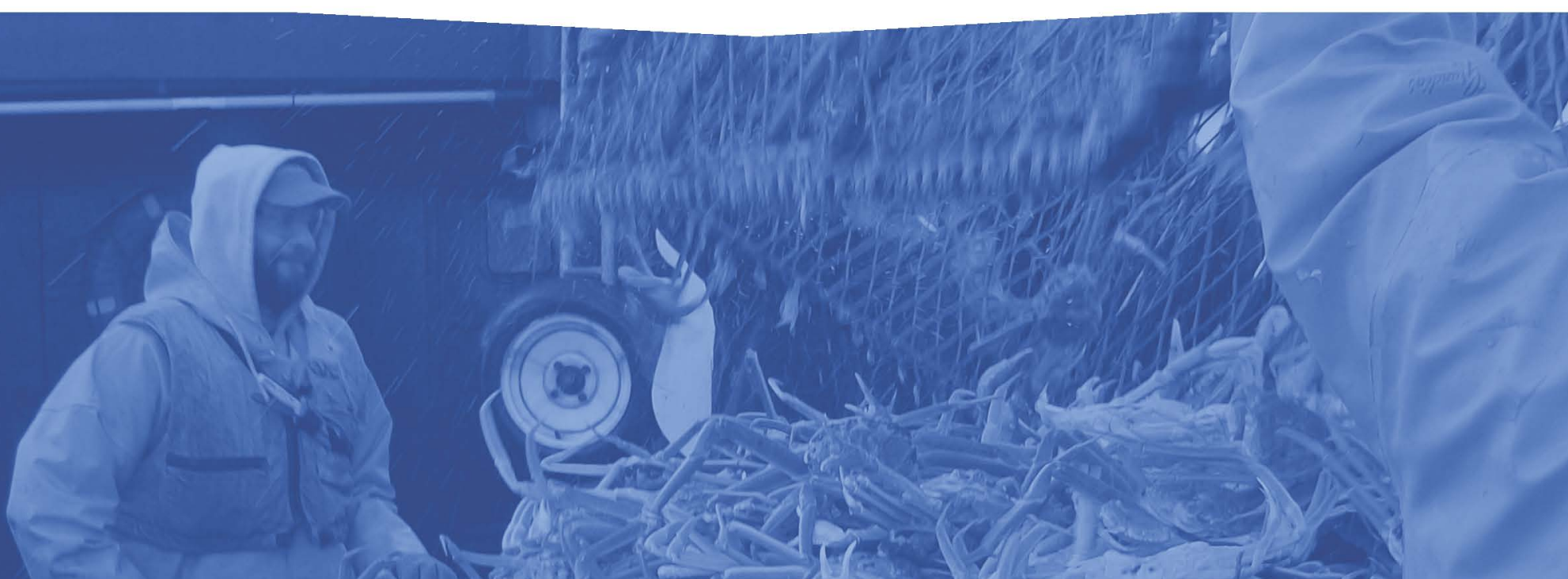